\title{
Paradigma morții extatice. $O$ comparație sugestivă
}

\author{
Andreea PREDA*
}

\begin{abstract}
The article aims to analyse "attitudes towards death", having as a theoretical perspective the concept of "noology" developed by academician Ilie Bădescu, and using a variety of documentary tools. Along with the professional experience from the "St. Irina" palliative care centre (developed by Dr. Pavel Chirilă), represented by assistance in the "passing to the Lord" of a significant number of patients, we will appeal to memorialistic, literary, patristic and anthropological sources which describe different attitudes towards death in the communist prisons, in literary works, in the monastic space and in the world of the Romanian peasant. Methodologically, apart from the conceptual introduction, these different hypostases of reporting to death, highlighted by the different documentary sources, will be analysed comparatively.
\end{abstract}

Keywords: death, modernity, communism, noology, detention.

\section{Introducere}

În plină epocă a exultării vieții fără de moarte și a evacuării, în consecință, a dovezilor ei de existență mai ales prin reconfigurarea culturii doliului, prin mascarea fizică a faptului că o persoană nu mai este printre noi, a căuta și a da un sens morții pare nu doar inutil, dar chiar reacționar. Alexandru Duțu, întemeietorul

* Lector Universitar Doctor la Facultatea de Teologie Ortodoxă „Justinian Patriarhul", Universitatea din Bucureşti; Membru fondator şi director (până în 2013) al Centrului de Îngrijiri Paliative „Sfânta Irina”, Bucureşti. 
școlii românești de studiere a mentalităților, vorbea deja acum două decenii în urmă despre „civilizaţia corpului” care definește modernitatea târzie în care ne aflăm ca vârstă istorică ${ }^{1}$.

Mai mult decât atât, ideologic, moartea este ,utilă” atunci când ne convine, că o putem invoca pentru a ne amenaja confortabil viața noastră proprie. Iată de ce, într-un asemenea context, este cumva de datoria teologiei, mai ales a celei aflate la confluența dintre Revelație și societatea care o primește, o refuză, o înțelege sau nu, să repunem în discuție chestiuni ,incomode”. Or, moartea rămâne de departe cea mai mare și inevitabilă incomoditate. În drum spre ea, tot încercăm să o amânăm iluzoriu, să ne facem ca și cum nu ne-ar privi personal. Ne reușește o asemenea păcăleală de sine o vreme, mai precis: până când, în familie sau cercul de prieteni, dăm nas în nas cu ea. $\mathrm{Cu}$ atât mai mult și mai intens o reîntâlnim dacă ne aplecăm asupra istoriei recente care a lăsat, în naţional-socialism sau în comunism, milioane de cadavre, toate dovezi că, într-adevăr, moartea nu este doar o chestiune personală, ignorată sau asumată, ci inclusiv o armă, o metodă, un crez politic, banalitate pentru unii (călăi) și oroare pentru alții (victime) ${ }^{2}$.

În rândurile de mai jos am să încerc să decupez câteva aspecte dătătoare de sens, tocmai pentru ca moartea să nu rămână o banalitate. Am să plec de la conceptul sociologic al academicianului Ilie Bădescu de ,noologie”, pentru ca apoi să dau

${ }^{1}$ Vezi Alexandru Duțu, Lumea dinăuntru și lumea din afară, ediția a II-a, îngrijită de Laurențiu Vlad, București, Edit. Universității din București, 2015. Vezi și articolul sintetic al editorului Laurențiu Vlad, „ "Lumea dinăuntru și lumea dinafară»: despre tradiții, solidarități și cultură politică; Pe marginea unor intervenții ale lui Alexandru Duțu în presa culturală și de opinie românească, 19901998", în Annals of the University of Bucharest / Political science series, 15(2), 2013, p. 95-107. Textul poate fi citit și în format digital la adresa https://nbnresolving.org/urn:nbn:de:0168-ssoar-398001.

${ }^{2}$ Despre dimensiunea criminală sistemică şi sistematică a comunismului, vezi recenta traducere a unei trilogii impresionante datorate lui Thierry WoLTON, $O$ istorie mondială a comunismului. Incercare de investigație istorică, București, Edit. Humanitas, 2018. Mai vezi și sinteza, mult mai scurtă, a lui Radu Preda, Comunismul. O modernitate eșuată, Cluj-Napoca, Edit. Eikon, 2009. 
Paradigma morții extatice.

O comparație sugestivă

un exemplu concret. $\mathrm{Nu}$ pot să nu menționez că problematica, teologică și culturală deopotrivă, a morții a reprezentat pentru mine o preocupare academică, dar nu mai putin una practică, mai ales în perioada în care am construit, alături de dr. Pavel Chirilă, și am coordonat Centrul de Îngrijiri Paliative „Sfânta Irina” din Voluntari. Așadar, abordarea este din ambele perspective: așa-zis teoretică (sociologia poate fi teoretică, dar nu și teologia!) și nemijlocită.

\section{Chipul ca dimensiune „noosică”}

Deloc întâmplător, punctul de plecare în lectura „,noologică” este de sorginte biblică. Or, potrivit antropologiei biblice, noologia chipului, cum o vede și concepe Ilie Bădescu, cuprinde în sine o triadă de reprezentaţii, fiind în realitate rezultatul întrepătrunderii a tot atâtea dimensiuni fiinţiale. Chipul noologic al omului include așadar chipul lui Dumnezeu, tinzând către asemănare (Facere 1, 26-27), care fiinţează în om, sufletului persoanei sau chipul interior, care se întipăreşte, reflectă şi defineşte chipul exterior, cel cu care ne identificăm ca persoane, chip ce moşteneşte anumite trăsături distincte familiei de proveniență. Omul este aşadar o fiinţă trinitară care înglobează într-un tot unitar lumea spirituală, lumea subtilă, adică o lume ce stochează şi integrează toate experienţele noologice, „sinele”, care îl ghidează pe om în exterior, în relaţia cu celălalt şi cea de-a treia lume care este cea corporală, carnală, grosieră.

„În om se regăsesc manifestările a trei lumi: spirituală, subtilă şi corporală (spiritus, anima, corpus), care sub diferite denumiri constituie creaţia propriu-zisă în toate doctrinele tradiţionale ale umanităţii"’3.

Aspectul tridimensional al chipului uman este rezultatul împreună-lucrării lui Dumnezeu cu persoana, mai precis cu libertatea acesteia. Înţelepciunea populară spune despre chip că este oglinda sufletului, tocmai pentru că acel chip pe care îl primim la naştere se modifică în funcţie de mişcările şi evoluţia interiorului, păstrându-şi în acelaşi timp bagajul genetic, trăsăturile fizionomice dominante ale

${ }^{3}$ René GuÉnOn, Criza lumii moderne, Bucureşti, Edit. Humanitas, 1993, p. 14. 
părinţilor şi rudelor noastre apropiate. Fiecare dintre noi venim cu o încărcătură moştenită de la moşii şi strămoşii noştri, cu o zestre ereditară plămădită de-a lungul mai multor generaţii şi pe care avem datoria de-a o îmbogăţi şi transmite mai departe urmaşilor noştri, într-un act sacru de perpetuare a neamului din care facem parte, parte a umanității, adică a unei Creații aflate de la început în marş spre Împărăţie, spre Ierusalimul Ceresc. Altfel spus, omul atinge nemărginirea datorită unor actualizări ale adâncului său noologic, prin actualizarea „latenţelor sale sufleteşti”, „orizonturi virtuale” ale trăirilor efective ${ }^{4}$. Tezaurul moştenit fiinţează în mod latent, actualizându-se în funcţie de capacitatea noastră de a pătrunde şi experia, dincolo de timp şi spaţiu, comuniunea cu Dumnezeu şi implicit cu toată făptura. Doar prin experienţele spirituale comune, împreună-trăiri şi împreună-simţiri, ne putem aduce aportul la bunul mers al lucrurilor în lume, începând cu propria familie.

Finitudinea apare în sociologia noologică, pe care continuăm să o luăm ca punct de referință, drept necesară. În consecință, moartea are, la propriu, un rost, o misiune. Descoperirea acestor dimensiuni reprezintă un drum nu doar de împăcare cu propria limită, cât mai curând o înțelegere a faptului că, murind, ne facem, așa zicând, treaba, că nu suntem simple victime sau accidente biologice, că inclusiv sau mai ales în clipa morții formăm, precum la naștere, o verigă de legătură nu doar între generații, dar și între trupesc și spiritual, între ceea ce se vede (moartea trupului) și ceea ce nu se vede (Învierea).

\section{Aspecte ale chipului surprinse în momentul morții}

Cum am precizat deja, în cele ce urmează mă ghidez după experiența acumulată în asistarea multor bolnavi internaţi în Centrul de Îngrijiri Paliative Sfânta Irina, instituţie destinată asistenţei medicale, sociale, psihologice şi spirituale a bolnavilor de cancer aflaţi în stadiu terminal pe care am construit-o, am conceput-o şi

4 Ilie BĂDESCU, Noologia - Cunoaşterea ordinii spirituale a lumii. Sistem de sociologie noologică, Bucureşti, Edit. Valahia, 2002, p. 288. 
Paradigma morții extatice.

O comparație sugestivă

coordonat-o alături de Prof. Univ. Dr. Pavel Chirilă, personalitate marcantă a societății româneşti, om de ideal şi cu credință de mare vizionar. În acest loc, timp de peste un deceniu, am avut ocazia să surprind, de mii de ori, momentul trecerii bolnavilor oncologici din „lumea de aici” în ,lumea de dincolo”.

Accesul nestingherit la patul bolnavului în calitate de membru al echipei, posibilitatea de a studia documentele medicale, sociale, psihologice şi spirituale aflate în camera asistentelor, discuţiile purtate cu bolnavii, dar şi cu familia şi persoanele apropiate, mi-au demonstrat şi întărit convingerea că există o legătură evidentă între modul în care a trăit acea persoană, a relaţionat cu ceilalţi, şi felul în care moare. Surprinzând persoanele în momentul morţii, am avut dorinţa să descifrez mai bine anumite trăsături ale chipului uman înainte de încetarea vieţii biologice. Am văzut oameni epuizaţi de suferinţă, aflaţi în incapacitatea de a-şi rezolva cele mai intime nevoi, imobilizaţi de multă vreme la pat, dar lucizi și împăcaţi cu viaţa lor, cu familia și cu Dumnezeu. Chipul acestor persoane mi-a întărit o dată în plus convingerea că viaţa omului nu se poate termina definitiv pe perna unui spital, că suntem mult mai mult decât un trup firav şi neputincios pe care cu greu se îndură, însă, să-1 părăsească chiar şi sufletul, duhul de viaţă care există în om. $\mathrm{Cu}$ certitudine că nu putem să descriem experienţa morţii în toată complexitatea ei, care rămâne intimă și personală, putem însă vorbi despre experienţa pe care o trăim când asistăm la moartea altcuiva. Experienţa morţii nu face parte din lumea noastră, poate doar în cazul unei morţi cerebrale, şi noi nu putem nici comunica, nici intra în legătură cu ea.

Putem spune doar că asistăm la un eveniment unic, cel mai irevocabil dintre toate: cu câteva clipe înainte, cineva era aici, puteam să comunicăm cu el, chiar dacă numai cu o privire, printr-o strângere de mână, ca apoi să avem dinainte un trup neînsufleţit, incapabil să mai reacţioneze la vreun stimul, să mai perceapă prezenţa noastră.

„Cadavrul aflat aici, în faţa noastră, poartă încă trăsăturile persoanei pe care am cunoscut-o, am iubit-o; fiinţa care trăia 
«înainte» e acolo, inutil să o căutăm în oricare altă parte din lumea noastră. Şi totuşi, nu mai e prezentă"5.

Pot să afirm că niciun chip nu m-a speriat, nu mi-a rămas în memorie ca ceva înfricoşător. Faptul că am putut comunica anterior cu acele persoane, chiar şi pentru câteva minute, cu unii poate doar printr-o atingere a mâinii, sau poate doar cu un zâmbet, a avut o semnificaţie aparte. Ideea de a ne fi întâlnit în acest spital, într-un moment crucial, faptul că am putut relaţiona pentru scurt timp, m-a făcut să asociez întotdeauna chipul muribundului cu istoria lui de viaţă, şi să-l respect şi să-L recunosc în chip tainic pe Hristos Cel dezbrăcat, flămâd şi însetat de veşnicie. Au fost bolnavi care mi-au dat senzaţia că dorm, că visează frumos, că în sfârşit au un somn odihnitor. Au fost situaţii în care am solicitat verificarea pulsului, chipurile respective dându-mi senzaţia că sunt încă în viaţă.

Se confirmă cumva că există anumite legături sufleteşti, spirituale, care continuă şi după încetarea din viaţă a omului.

„Sunt acele «latenţe», sau «locuri categoriale ale funcţiunilor sufleteşti», care se dovedesc a fi tot atâtea categorii virtuale ale sufletului popular. Pe acest substrat sufletesc se clădeşte spiritul individual şi colectiv. Şi tocmai prin acest substrat sufletesc ni se revelează cele necreate, latenţele sufleteşti. Ele se manifestă ca «realităţi simţuale», ca realităţi ale simţirii generale”. Latenţele sufleteşti sunt unificatoare în indivizi dar şi între indivizi - şi astfel se explică această ,împreună simţire" mai cu seamă în apropierea momentului limită, care este moartea, care are la bază acele realităţi sufleteşti primare, nesădite în om prin fapte de educaţie şi cultură din lumea aceasta, ele ţinând mai degrabă de latura spirituală a fiinţei umane, înnobilată prin creaţie, cu simţire, cu ,suflet viu”6.

Desigur, cum era de așteptat, am văzut şi chipuri triste de muribunzi care transmiteau mesajul că lăsau parcă lucrurile neterminate, unele poate chiar și neîncepute, dar dorite, și care, în consecință, şi-ar mai fi dorit să rămână puţin printre noi. Mai ales în

\footnotetext{
5 Marco PuCCIARInI, Moartea şi experienţa morţii, București, Edit. Ars Longa, 2004, p. 11.

${ }^{6}$ Ilie BĂDESCU, op. cit., p. 258.
} 
Paradigma morții extatice.

O comparație sugestivă

asemenea situații, nimeni nu are voie să moară singur, moartea fiind un moment ,greu”, la propriu, inacceptabil prin brutalitate și rapiditate. Una peste alta, cred că am înțeles că mult citatei „,calități a vieții" îi corespunde, în oglindă, o suprinzătoare dar deloc abstractă „,calitate a morții”. Pentru a putea descrie însă mai bine chipurile muribunzilor asistaţi personal, mă voi folosi de talentul unor scriitori/martori care au surprins la rândul lor aceste trăsături şi le-au descris cu mult rafinament sufletesc și intelectual.

\section{3. „Expresii" și „mesaje” ale chipului uman în momentul morții}

Regretatul Părinte Gheorghe Calciu-Dumitreasa, trecut prin experiența cruntă a detenției anticomuniste, descrie un astfel de moment (sublinierile îi aparțin):

„Eram la Jilava, într-o celulă specială de exterminare, în 1957. $\mathrm{Cu}$ mine în celulă mai erau Marcel Petrişor, Iosif Iosif şi Costache Oprişan. Costache avea plămânii complet distruşi de tuberculoză şi noi îl păzeam zi şi noapte pentru ca să nu moară fără rugăciunea noastră. Pentru că făcusem doi ani de medicină, am dorit ca eu să am grijă de el, pentru că Oprişan era un adevărat sfânt, sprijinul nostru moral în acea celulă a morţii şi lumina noastră spirituală. Într-o dimineaţă, ni s-a dat maşina de bărbierit. În timp ce eu mă bărbieream, Marcel îl păzea pe Costache. L-am auzit cum m-a strigat într-o şoaptă disperată şi pătrunzătoare: Ghiță, moare Costache! M-am întors fulgerat spre pat, cu disperare şi 1-am văzut pe Costache murind. Ochii lui erau deschişi, dar peste ei căzuse un văl ceţos al morţii şi am ştiut că Marcel nu se înşelase: Costache murea. M-am repezit la el, l-am prins cu spaimă de moarte de umerii osoşi, el nu mai era decât un schelet, 1-am scuturat şi am strigat cu aceeaşi şoaptă pătrunzătoare a lui Marcel, pentru ca nu aveam voie să vorbim tare: "Costache, nu muri! Nu pleca! Întoarce-te Costache!» Şi Costache s-a întors. Am văzut ochii lui reluându-şi strălucirea vieţii, vălul a dispărut de pe pupilele lui, dar, în aceeaşi clipă, ochii i s-au umplut de o 
groază necuprinsă, faţa lui s-a boţit cu înfiorare ca aceea a unui nou-născut şi a început să scâncească exact ca un prunc. M-am îngrozit şi m-am retras, permiţându-i să moară. Faţa i s-a destins, ochii i s-au închis, ridurile i-au dispărut şi o lumină cerească a apărut pe obrajii lui"”

Aşa descrie unul din supravieţuitorii închisorilor comuniste, care a executat 21 de ani de puşcărie politică, trecând totodată prin experimentul reeducării de la Piteşti, moartea lui Constantin (Costică) Oprişan. Vălul ceţos al morţii este un element general valabil pe chipul muribundului. E semnul cel mai elocvent al momentului crucial, al trecerii din ,lumea de aici” în ,lumea de dincolo". Se întâmplă de multe ori ca faţa bolnavului aflat în stadiu terminal să capete o lumină, sau din contră, o întunecime, cu mai mult timp înainte de instalarea morţii, chiar cu câteva zile mai devreme. Moartea „,bună” şi „frumoasă” este sfârşitul unei vieţi modelată creştineşte, a unei ,vieţi juste şi sfinte petrecute în lume"8.

Moartea lui Costică Oprişan este moartea unui om care a suferit mult, care a reprezentat pentru colegii de temniță un model de demnitate umană, un caracter probat în împrejurări dintre cele mai grele, în situaţii limită, când de cele mai multe ori fiinţa umană este dispusă să cedeze în faţa unor presiuni care au depăşit cu mult sfera umanului. A fost asimilat ca ,sfânt” de către camarazii săi, rămânând în memoria lor pentru sprijinul moral şi lumina spirituală care i-a ajutat să reziste. Costică Oprişan şi cei menţionaţi mai sus fac parte din generaţia interbelică, care pare să fi înţeles exact menirea şi misiunea ei. „Această generaţie şi-a asumat suferinţa şi moartea pentru neamul în care s-a născut" 9 .

Dragostea cu care a fost înconjurat acest om este cu mult superioară dragostei cu care sunt asistaţi bolnavii în centrele destinate îngrijirilor paliative. Dezideratul instituţiilor de îngrijiri

7 Gheorghe CAlciu-Dumitreasa, Rugăciune şi Lumină Mistică, Cluj-Napoca, Edit. Dacia, 1998, p. 125.

${ }^{8}$ Philip ARIES, L'homme devant la mort, vol. I, Paris, 1977, p. 23.

9 Nae Ionescu, Constantin Papanace, Destinul unei generaţii, Bucureşti, Edit. Scara, 2002, p. 6 . 
Paradigma morții extatice.

O comparație sugestivă

paliative este acela de a nu exista nicio persoană bolnavă care să moară singură, neasistată. Dar moartea unui bolnav în hospice este moartea unui persoane de care nici familia nu mai este dispusă să se îngrijească. Motivele sunt dintre cele mai diverse: lipsa timpului, neputinţa de a administra tratamentul medical, incapacitatea îngrijirii unui bolnav imobilizat la pat, dar și, destul de des, indiferenţa pentru persoana în cauză. Pur și simplu. La fel ca şi moartea lui Oprişan, moartea celor din hospice este o moarte instituţionalizată. Dar moartea lui Oprişan este o moarte care impresionează, o moarte care nu trece neremarcată, deşi se produce într-un loc dezonorant la prima vedere, ca un deţinut de drept comun, capabil să pună în pericol utopica orânduire socială.

„În mod normal omul se află $̂$ in ceva, stând sub o totalitate ori alta a naturii şi societăţii, unde n-are, ca ins, nici fiinţă, nici nefiinţă. Omul e astfel, «nenumărat», adică e un exemplar între exemplare, ca într-o simplă teorie a mulţimilor. Închis aşa, el se găseşte dinainte predat statisticii ... De unde începe devenirea, fie cea istorică a colectivităţilor, fie cea individuală? De unde încep, pentru om, sorţii de-a ieşi din statistică?

În cazul insului, e limpede: când intră sub atracţia unui adevăr, a unui sens de viaţă ori a unei idei modelatoare, el înfrânge condiţia de $a$ fi în, şi trece în cea de a fi întru ceva"

Constantin Noica reuşeşte într-un mod unic să diferenţieze omul obişnuit de omul de valoare. Oprişan are ocazia de a fi întru. Pentru că moartea lui Oprişan are la bază jertfa creatoare, ca şi în balada Meşterului Manole: sacrificiul uman menit să zdruncine aşezarea nefirească a lumii, fiind, de fapt, un semn de protest, un semnal de alarmă tras pentru cei care nu vor să înţeleagă rostul adevărat al vieții.

Referind-se la ideea de sacrificiu uman, Mircea Eliade descifrează şi el miturile româneşti ale morţii, identificând „o viziune arhaică şi totodată creştină: moartea e jertfa supremă, e un mister prin care omul se desăvârşeşte, dobândind un mod superior

${ }^{10}$ Constantin NoICA, Sentimentul românesc al fiinţei, Bucureşti, Edit. Humanitas, 1996, p. 170. 
de a fi în lume. Pentru că, pentru români, ca şi pentru atâtea alte culturi, moartea nu e extincţie, nici măcar o împuţinare a existenţei - ci un fel de a fi, o nouă existenţă pe un alt nivel, mai aproape de Dumnezeu"11.

Se ştie că valorificarea morţii constituie una dintre cele mai fecunde victorii ale Creştinismului. Se ştie, de asemenea, că o cultură are cu atât mai multe şanse de a deveni universală, cu cât îşi pune mai curajos problema morţii. Se pare că „şansa" generaţiei interbelice, cea care a umplut pușcăriile și lagărele de muncă ale dictaturii proletariatului, a fost aceea de a crea caractere şi repere pentru mulţi ani în cultura românească tocmai prin asumarea, pe parcurs, a statutului de generaţie de sacrificiu.

Un alt portret pe care îl voi prezenta este cel al Stareţului Zosima (Sfântul Ambrozie de la Optina), zugrăvit de Dostoievski în mod inspirat:

„Intrând cu inima strânsă de grijă, sfâşiat de durere, în chilia stareţului, Aleoşa se opri în prag, uluit; ... îl văzu stând în jilţ, ca o umbră, dar vesel şi luminos la faţă ... ”12 [...] „Cu cinci minute înainte de moarte, după cum povesteau mai apoi, nimeni dintre ei nu s-ar fi gândit că o să se prăpădească. Bătrânul a simţit deodată o săgetătură în piept, s-a făcut alb ca varul şi şi-a apăsat cu putere mâinile pe inimă. Într-o clipă au sărit cu toţii în picioare şi s-au repezit să-l ajute; aşa suferind cum era, stareţul le-a zâmbit şi, lăsându-se să alunece cu încetul din jilţ pe podea, cu faţa la pământ şi braţele desfăcute, luminat de o fericire extatică, a sărutat pământul, precum el însuşi îi învăţase mai înainte, apoi, şoptind o rugăciune, şi-a dat sufletul în tihnă şi bucurie"13.

Există o artă a vieţii pe care, de obicei, cei mai mulţi dintre noi nu ne-o însuşim decât în clipa în care trebuie să părăsim viaţa.

${ }^{11}$ Mircea Eliade, Arta de a muri, ediţia a II-a, Cluj-Napoca, Edit. Eikon, 2006, p. 242.

${ }^{12}$ F. M. Dostolevski, Fraţii Karamazov, ediţia a II-a, Bucuresti, Edit. Leda, 2005, p. 409.

${ }^{13}$ Ibidem, p. 474. 
Paradigma morții extatice.

O comparație sugestivă

Modelele prezentate până acum ne dau convingerea că putem să ne pregătim moartea prin felul în care ne trăim viaţa. Așa calitatea vieții devine, la propriu, arvuna calității morții. Să recunoaștem: pentru omul modern, autonom, emancipat de sub autoritatea narativului explicativ de natură religioasă, dar cu atât mai dispus să cedeze în fața puterii profane, să se înscrie voluntar în scenariile acesteia, o asemenea abordare pare morbidă, incompatibilă cu bucuriile și deliciile vieții.

\section{Chipul muribundului în tradiția populară}

Înţelepciunea populară ne arată şi ea, într-o manieră simplă dar plină de profunzime, atitudinea pe care trebuie s-o avem în faţa muribundului. Concret, cu cuvintele marelui sociolog și antropolog Ernest Bernea:

„Un alt fapt semnificativ care poate îngreuna momentul morţii este acela al strigării lui de către cei apropiaţi în grad de rudenie. Dacă nevasta sau un copil îi spune: «da vai, cui ne laşi» sau altă lamentaţie, omul se-ntoarce şi nu poate muri, uneori cate 2-3 zile. Această credinţă face ca în acest moment să nu fie lăsaţi aproape de muribund dintre cei din familie"14.

Remarcăm asemănarea între schimonosirea chipului lui Costică Oprişan la strigarea lui de către camaradul ce îl îngrijea şi problema semnalată prin tradiţia populară, atunci când muribundul nu este lăsat să moară în linişte. Se pare că starea noastră de zbucium interior îl poate influenţa negativ pe cel ce tocmai se pregăteşte ,să plece” de lângă noi.

„O altă îndatorire a celor ce priveghează este de a păstra în momentul morţii o desăvârşită linişte. Când au ceva de vorbit îşi fac semn şi merg afară sau în curte. Există un moment solemn al morţii pe care oamenii îl respectă"'15.

${ }^{14}$ Ernest BerneA, Moartea şi Înmormântarea în Gorjul de nord, București, Edit. Cartea Românească, 1997, p. 23.

${ }^{15}$ Ibidem, p. 26. 
Omul ancestral, deşi needucat, intuia cu precizie momentele cruciale ale vieţii, având prezenţă de spirit, ştiind cum să se comporte firesc. Tocmai această naturaleţe, acest bun-simţ înnăscut, nobleţea lui sufletească 1 -au ajutat să trăiască frumos şi să moară cu demnitate.

„Când trage să moară cineva, nu e bine să vorbească tare în casă; mai mult prin semne. Lasă omu' să-şi dea sufletul în linişte; omul şi aşa e în chin"16.

Ţăranul realizează suferinţa prin care trece muribunul, ştie că „e în chin”, nu este egoist, nu se exteriorizează, este discret, suferă în tăcere, iar durerea lui este mai mare decât a celui ce şi-o exteriorizează, dar ştie că aşa e bine pentru muribund.

„Când moare se arată cum i-a fost inima pe toată viaţa. Care vede frumos închide ochii şi doarme liniştit, care vede urât se înfricoşează de faptele lui; viaţa i s-arată aşa cum a fost" ${ }^{\prime 17}$.

Această afirmaţie se probează de multe ori în instituţia în care am lucrat, unde am avut ocazia să văd oameni murind.

„Când trage un om să moară, se strâmbă în tot felul - uneori şi lăcrimează. Moartea când vine îi dă paharul ei să-l bea şi trebuie să-1 bea până la fund că bietu' om n-are ce face"18. [...], ,La moartea unui om, o femeie din ţara Oltului a spus: «să-i fie sfârşitul ca şi începutul», ceea ce ne dovedeşte că în credinţele populare tradiţionale sfârşitul se transformă, desigur pe un alt plan decât acela al lumii sensibile, în eternitate, unde este totuna cu începutul"'19.

Iată aşadar că lumea în mijlocul căreia trăia ţăranul român era pentru el una creată, însă nu la întâmplare, ci într-o formă în care echilibrul şi armonia domină. Lumea noastră, în toate formele şi calităţile ei, are o ordine care stăpâneşte totul, chiar şi atunci când fenomenele anormale se petrec în mod neprevăzut.

„Şi dacă lucrurile ies din ordinea lor obişnuită, ele nu sunt mai puţin în ordine, şi ceva care nouă ne poate apărea ca ceva

\footnotetext{
16 Ibidem, p. 24.

${ }^{17}$ Ibidem, p. 22.

${ }^{18}$ Ibidem, p. 23.

19 Ernest BerneA, Spaţiu, timp şi cauzalitate la poporul român, Bucureşti, Edit. Humanitas, 1997, p. 153.
} 
Paradigma morții extatice.

O comparație sugestivă

nefiresc este tot atât de ordonat, dar într-o altă ordine decât cea obişnuită" 20 .

Moartea însăşi este integrată aici, dar este biruită prin eternitatea întregului, prin armonia existenţei.

„Lucrurile sunt în aşa fel întocmite că se leagă unul de altul, când suferă într-un loc, suferă toate. Vezi, lumea-i întocmită bine, că altfel nici nu s-ar ţine.

Vine moartea, dar ea nu biruie; biruie viaţa. Pentru aceasta lumea rămâne lume şi noi rămânem oameni" ${ }^{21}$ [...].

„Facerea lumii şi Judecata de Apoi sunt stâlpi de sprijin ai minţii. Timpul curge fără încetare între aceste două mari momente începutul şi sfârşitul vieţii omului ..."22.

\section{5. „Chipul” în Biblie și în scrierile Sfinților Părinți}

Chipul omului ascunde în mod tainic chipul lui Dumnezeu. „Chipul slavei Tale celei negrăite sunt, deşi port rănile păcatului" "23, aflăm din slujba de înmormântare, ca o garanţie optimistă a nemuririi noastre. Chiar dacă trupul se descompune, sufletul omului continuă să trăiască în continuare, dar în mod nevăzut. Înţeleptul Solomon ne învaţă că întotdeauna faţa, chipul, este imaginea inimii; între cele două există canale de comunicare neţesute şi, privind la faţa omului, îi cunoaştem şi inima - „o inimă veselă înseninează faţa ...” (Pilde 15, 13). Starea din afară a feţei obişnuieşte să se schimbe cu starea dinlăuntru a sufletului. Chipul omului exprimă veselia sau tristeţea inimii, datorită gândurilor care domină mai mult raţiunea umană în acele momente. Alteori, omul se schimbă odată cu faţa lui, spre lumină.

Sfânta Scriptură ne înfăţişează prin diverse exemplificări semnificaţia chipului uman:

${ }^{20}$ Ibidem, p. 44.

${ }^{21}$ Ibidem, p. 68.

22 Ibidem, p. 22.

23 ***, Panihida, ediţia a III-a, Iași, Edit. Trinitas, 2000, p. 67. 
- Dumnezeu a suflat în faţa omului ,suflare de viaţă”;

- faţa lui Iisus s-a schimbat în lumina taborică ca un semn mesianic „faţa Lui era ca soarele când străluceşte în puterea lui" (Matei 17, 2);

- faţa diaconului Ştefan, primul martir al creştinismului, a fost văzută ca fiind a unui înger (Fapte 6,15$)$.

„Nu-ţi întoarce faţa Ta de la mine, ca să nu mă asemăn celor ce se coboară în mormânt" (Psalm 142, 7) ${ }^{24}$. Iată puterea chipului lui Dumnezeu, care a fost sădit în om, şi fără lumina căruia omul nu poate discerne binele de rău, frumosul de urât.

Sfântul Marcu Ascetul crede că felul în care se derulează sfârşitul nostru arată relaţia inimă-suflet care, la rândul ei, exprimă petrecerea vieţii trecute; dacă omul a fost foarte ataşat de materie şi plăceri, în momentul morţii, inima devine ,închisoare şi lanţ" sufletului, prelungind chinuitor despărţirea de trup ${ }^{25}$. Aceasta este încă o mărturie a importanţei pe care o are felul în care ne-am trăit viaţa.

Faţa omului bun răspândeşte lumină, de aceea sfinţii au în icoane capetele înconjurate de un nimb luminos. Omul bun e omul care zâmbeşte luminos, în bucuria comuniunii, iar în momentul morţii, chipul său poate păstra încă lumină şi linişte. Chipul său îi va putea odihni pe cei din jur, dându-le nădejdea că şi sufletul celui drag se odihneşte, nesuferind nicio durere, boală, neputinţă.

„Toate acestea reprezintă un program pentru înnobilarea reală a omului. Şi numai în comuniunea bucuroasă cu alţii, aşa cum e practicată de poporul român, se înnobilează omul. Numai în comuniune se înaintează la nesfârşit în această nobleţe şi în descoperirea fără sfârşit a tainei omului, care se hrăneşte din taina comuniunii între Persoanele Sfintei Treimi" ${ }^{26}$.

${ }^{24}$ Biblia sau Sfânta Scriptură, Ediţia Sinodală, Bucureşti, Edit. Institutului Biblic şi de Misiune al Bisericii Ortodoxe Române, 1988.

25 Pavel ChIRILĂ, Mihai VALICĂ, „Elemente de anatomie spirituală a corpului omenesc", în Studii de medicină şi filantropie creştină, Bucureşti, Edit. Christiana, 2001, p. 45-46.

${ }^{26}$ Ibidem, p. 204. 


\section{În loc de concluzie}

Asemeni lumii pe care o deschide, a veșniciei, moartea nu poate fi epuizată în cuvinte sau observații empirice. De aceea, alături de iubire, moartea a inspirat creatorii lumii, iar limbajul cel mai potrivit a rămas de milenii același: liric. Adică plămada de neputință și nădejde, nectarul muritorilor. O expresie, dintre multele, o găsim la Daniel Turcea, unul dintre cei care a scris probabil unul dintre cele mai tulburătoare jurnale personale ale întâlnirii cu de-ne-evitatul. Astfel, în „Balada păsării”:

„vie Lumină

venind, pe cale

inima-mi cere

pasăre lină

sufletu-n lacrimi

vrea, fără vină

numai să-1 apere

numai să-l poarte

sus

peste moarte".

Sau în „Racla de lumină”:

„viaţa-mi

puţină

trupul

îngândurat

îngroapă-le

vii

în lumină

de-ar muri

tot ce nu e

în mine

curat

ţărâna 
şi gândul

preaiubind

le sfinţeşti

să nu mai ştiu

să nu mai ştiu

dacă mai sunt

sau doar Tu eşti

viaţa-mi

puţină

trupul

îngândurat

uşor

mi le-ngroapă

de vii

în lumină”.

În fine, în „Murim pentru a nu muri”:

„murim pentru a nu muri

ori vom arde de tot pe rugul însetării

jertfă de taină fiind

mistuindu-ne-n duh

pentru a fi pururea vii

murim spre viaţă

sau murim spre moarte

se veştejesc şi pier, nu voi cânta

nu voi cânta nicicând frunzele toamnei

cele ce se veştejesc şi pier

toamnă a lucrurilor

nici ziua

când stelele se vor prăbuşi într-o vreme a lor

deasupra adâncului

nu aceste lucruri le voi iubi

şi nu voi dori sufletului meu

strălucirea pietrelor, nici lauda

nici valurile

ce moarte sunt, lăcaşuri de morţi 
Paradigma morții extatice.

O comparație sugestivă

când un Egipet de piatră înalţă

imense sarcofage cu nimic mai de preţ

decât paşii pe nisipuri

e o durere desigur

a-nfrângerii

Ca şi cum trupul ce doare şi plânge

de-ar fi imens, din granit

ar fi veşnic

cum ne-am putea amăgi

când nici cei ce lucrau în deşert

nu mai credeau în nimic

nu mai credeau şi ştiau

ştiau

că zidesc o ruină

cu o voluptate a morţii

Egipet al fricii',27.

$\cos 80$

\section{Bibliografie}

1. *** Panihida, ediţia a III-a, Iași, Edit. Trinitas, 2000.

2. ARIES, Philip, L'homme devant la mort, vol. I, Paris, 1977.

3. BĂDESCU, Ilie, Noologia - Cunoaşterea ordinii spirituale a lumii. Sistem de sociologie noologică, Bucureşti, Edit. Valahia, 2002.

4. BERNEA, Ernest, Moartea şi Înmormântarea în Gorjul de nord, București, Edit. Cartea Românească, 1997.

5. BERNEA, Ernest, Spaţiu, timp şi cauzalitate la poporul român, Bucureşti, Edit. Humanitas, 1997.

6. Biblia sau Sfânta Scriptură, Ediţia Sinodală, Bucureşti, Edit. Institutului Biblic şi de Misiune al Bisericii Ortodoxe Române, 1988.

7. CAlciu-Dumitreasa, Gheorghe, Rugăciune şi Lumină Mistică, Cluj-Napoca, Edit. Dacia, 1998.

27 Vezi site-ul http://danielturcea.blogspot.com/2007/12/poezii-de-danielturcea.html. 
8. CHIRILĂ, Pavel, Mihai VALICĂ, „Elemente de anatomie spirituală a corpului omenesc", în Studii de medicină şi filantropie creştină, Bucureşti, Edit. Christiana, 2001.

9. Dostolevski, F. M., Fraţii Karamazov, ediţia a II-a, Bucuresti, Edit. Leda, 2005.

10. DuȚU, Alexandru, Lumea dinăuntru și lumea din afară, ediția a IIa, îngrijită de Laurențiu Vlad, București, Edit. Universității din București, 2015.

11. EliADE, Mircea, Arta de a muri, ediţia a II-a, Cluj-Napoca, Edit. Eikon, 2006.

12. GUÉNON, René, Criza lumii moderne, Bucureşti, Edit. Humanitas, 1993.

13. IONESCU, Nae, Constantin PAPANACE, Destinul unei generatii, Bucureşti, Edit. Scara, 2002.

14. NoICA, Constantin, Sentimentul românesc al fiinţei, Bucureşti, Edit. Humanitas, 1996.

15. PredA, Radu, Comunismul. O modernitate eșuată, ClujNapoca, Edit. Eikon, 2009.

16. PUCCIARINI, Marco, Moartea şi experienţa morţii, București, Edit. Ars Longa, 2004.

17. Wolton, Thierry, $O$ istorie mondială a comunismului. Incercare de investigație istorică, București, Edit. Humanitas, 2018. 